原著

乳腺腫瘍における ${ }^{99 m} \mathrm{Tc}-\mathrm{MIBI}$ シンチグラフィーの有用性の予備的検討 恵寿総合病院外科・胃腸科

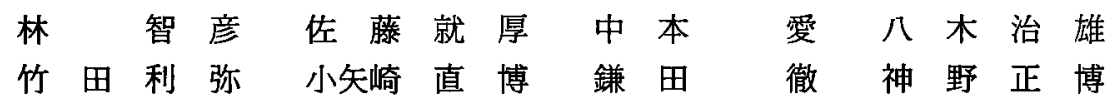

当科における過去 2 年 2 力月間に ${ }^{99 \mathrm{~m}} \mathrm{Tc}$-2-methoxy isobutyl isonitrile (MIBI) シン チグラフィーを施行し, 病理組織診断を得た乳腺腫瘍33例（良性 5 例, 悪性28例）を対 象に検討を行った. $600 \mathrm{MBq} の^{99 \mathrm{~m}} \mathrm{Tc}-\mathrm{MIBI}$ を静注し, $\gamma$ カメラにて early と delayed SPECT 撮影をし評価した. ${ }^{99 m} \mathrm{Tc}$-MIBI の良悪性の診断における有病正診率 $96 \%$, 無病 正䛦率 $100 \%$ ，正診率 $97 \%$ であり，リンパ節転移診断に関してはそれぞれ $58 \% ， 100 \%$, 81\%であった．抗癌剈の耐性と関連すると言われている wash out を認めた割合は悪性 腫瘍 39 病変中 14 病変 $36 \%$ に認められた。 ${ }^{99 m} \mathrm{Tc}-\mathrm{MIBI}$ は乳腺腫湯の良悪性の鑑別診断お よびリンパ節転移診断に有用であり, 今後化学療法の耐性との関連を調査する必要があ ると考えられた.

索引用語：乳癌, 腋窝リンパ節転移, ${ }^{99 m} \mathrm{~T}$ c-MIBI SPECT

はじめに

元来, ${ }^{99 m} \mathrm{Tc}-2$-methoxy isobutyl isonitrile (以下 MIBI とする) は心筋血流イメージング製羭として開 発されたが，腫場検索にも有用であるといわれてい $ろ^{132)}$. 乳癌の画像診断において従来のマンモグラフィ 一, 孚腺超音波検查, MRI などに加えて, 最近 ${ }^{99 m} \mathrm{Tc}-$ MIBI を用いた乳腺シンチグラフィーが乳腺腫湟の良 悪性の鑑別診断や腋裔リンパ節転移の診断に有用であ りまた抗癌㓮の感受性の評価に役立つと報告されて いる3.．そこで今回われわれは，乳腺腫瘍における ${ }^{99 m} \mathrm{Tc}-\mathrm{MIBI}$ の有用性を検討したので報告する.

\section{対象および方法}

1997年 8 月から 1999 年 9 月までの 2 年 2 カ月間に, 当院にて ${ }^{99 m}$ Tc-MIBI を施行し生検または手術にて病 理組織診断を得た 33 例を対象とした。 その内訳は良性 腫瘍が 5 例（乳腺症 1 例, 腺維腺腫 3 例, 康痕組織 1 例) で，悪性腫瘍は再発 2 例を含む28例（乳頭腺管癌 11例, 充実腺管癌 8 例, 硬癌 5 例, 粘液癌 2 例, 邻有様 癌 1 例, 扁平上皮癌 1 例) であった。撮影方法は, ま ず乳腺腫場の存在する対側上肢から $600 \mathrm{MBq}$ の $^{99 \mathrm{~m}} \mathrm{Tc}$ -MIBI を静注する.患者を仰臥位として両腕を挙上さ せ, 両側乳房と腋窩を撮影範囲とした. 使用した装置 は, PIKER 社製の対向式 $\gamma$ カメラ PPISM2000XP

1999年 5 月10日受付 2000 年 4 月 26 日採用
で, 静注20分後の early image と180分後の delayed image を収集し, オンラインデータ処理装置 ODYSSEY-UP を用いてコンピューター断層画像 (SPECT) を作製した。撮像条件は $128 \times 128$ マトリックス 4 ステテ ップの $360^{\circ}$ 収集で一検査約 25 分であった. early image と delayed image の両方あるいはどちらかにおいて 前胸部および腋窩部に異常集積が認められるものを悪 性およびリンパ節転移陽性と診断し（図 1, 図 2), early imageにて異常集積が認められるが delayed imageで減少が視覚的な判定で認められるものを wash out ありと診断した (図 3).この視覚的評価と 病理組織所見と比較した。

なお, 統計学的有意差検定には $\chi^{2}$ 検定を用い, $\mathrm{p}<$ 0.05をもって有意差ありとした。

\section{1. 原発巣の診断能}

結果

悪性腫場28例の内, 27 例に前胸部に異常集積を認め た。また, 良性腫瘍は 5 例と少ないが全例に異常集積 は認めず，すべての症例で鑑別可能であった，異常集 積の有無を良悪性の鑑別に用いた場合，原発巣におけ る ${ }^{99 m} \mathrm{Tc}-\mathrm{MIBI} \sigma$ 有病正診率 $96 \%$, 無病正診率 $100 \%$, 正診率 $97 \%$ ああり，有意に高率であった。また，描出

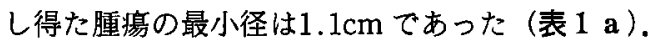

\section{2.リンパ節転移の診断能}

悪性腫瘍28例の内, 再発 2 例を除いた26例では, 病 


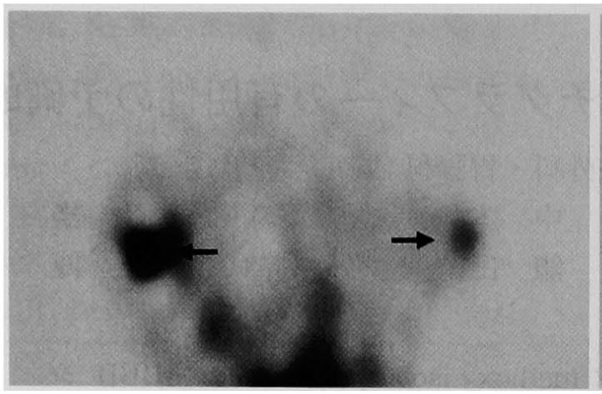

early image

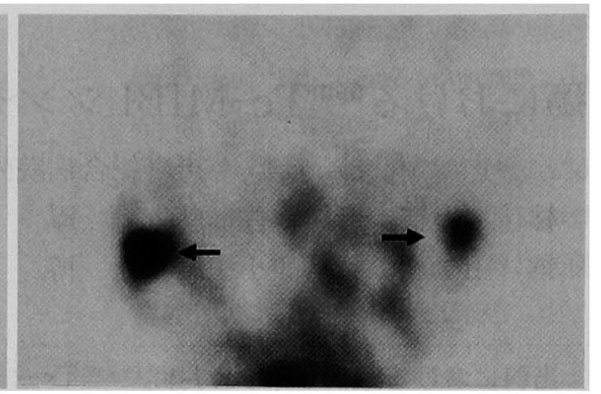

delayed image

图 1 99mTc-MIBI 乳腺シンチグラフィーによる乳癌の診断

41歳女性. 両側乳癌患者の冠状断の画像で, early および delayed image の両方において左右 の乳腺腫㰾への ${ }^{99 m} \mathrm{Tc}-\mathrm{MIBI}$ の取り込みが認められ，悪性と診断した。

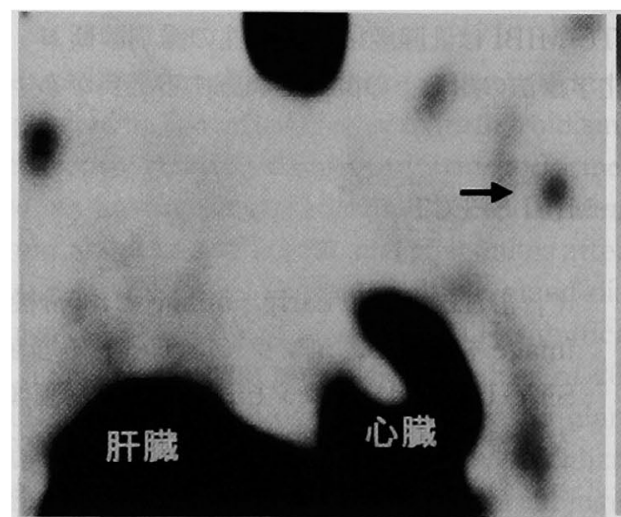

early image

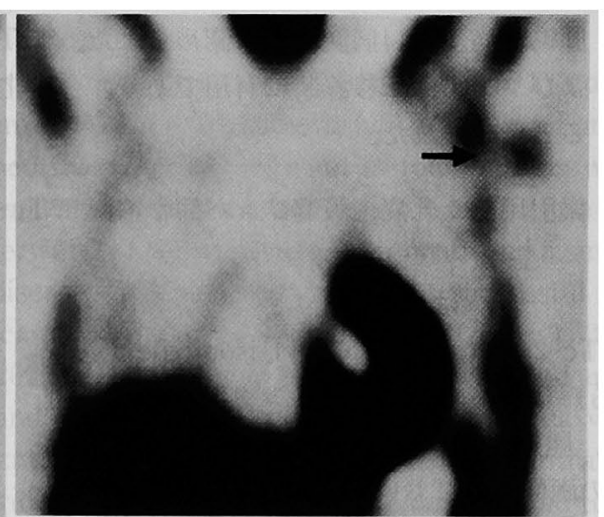

delayed image

図 $2{ }^{99 m} \mathrm{Tc}-\mathrm{MIBI}$ 乳腺シンチグラフィーによる腋窩リンパ節転移の診断

51歳女性. 左乳癌患者の冠状断の画像で, early および delayed imageの両方において左腋窩 に ${ }^{99 m} \mathrm{Tc}-\mathrm{MIBI}$ の取り込みを 1 個認め,リンパ節転移陽性と診断した。

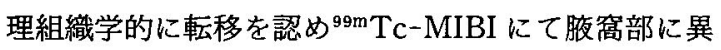
常集積を認めたものは 7 例で, 病理組織学的に転移を

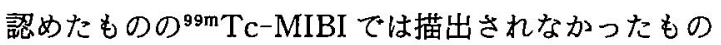
は 5 例，病理組織学的に転移を諗めず99mTc-MIBI で も描出されなかったものは14例であった，悪性腫瘍に おける ${ }^{99 \mathrm{~m}} \mathrm{Tc}-\mathrm{MIBI} の$ 腋窩リンパ節転移診断に関する 有病正診率は $58 \%$, 無病正診率は $100 \%$, 正診率 $81 \%$ で あり，有意に高率であった（表 1 b).

\section{3. wash out $の$ 診断}

ある種の抗癌㓮に耐性と関連すると考えられている wash out 例について検討した。 wash outを認めた割 合は悪性腫瘍39病変中14病変 $(36 \%)$ に認められた。 内訳は乳腺腫瘍26例, 腋窩リンパ節10例, その他（肺 転移 2 例, 胸骨傍リンパ節 1 例) であり，その中で wash out を認めた病変はそれぞれ乳腺腫瘍では 8 例,
腋窩リンパ節では 6 例であり,その他に病変には認め なかった(表 2 ). また中には 1 症例で複数病変が存在 し,それぞれの部位で wash out の程度が異なる場合 も認められた。

\section{考察}

${ }^{99 \mathrm{~m}} \mathrm{Tc}$-MIBI は, 腫瘍にも取り込まれることより腫 湯シンチグラフィーとして応用可能であることが報 告2゙され，さらに薬郕耐性と関連があることが報告いさ れた. そのため原発性乳癌, 転移性乳癌の検査法とし ての有用性だけでなく, 抗癌咸に対しての感受性評価 にも有用となりうる可能性がある.今回の検討では ${ }^{99 \mathrm{~m}} \mathrm{Tc}-\mathrm{MIBI}$ は乳腺腫瘍の原発巣の良悪性の鑑別診断 に高い有病正診率 $(96 \%)$, 無病正診率 $(100 \%)$, 正診 率 (97\%) を示したが, これらは他の報告5と同様であ った. 今回の症例では false negative を 1 例認めたが, 


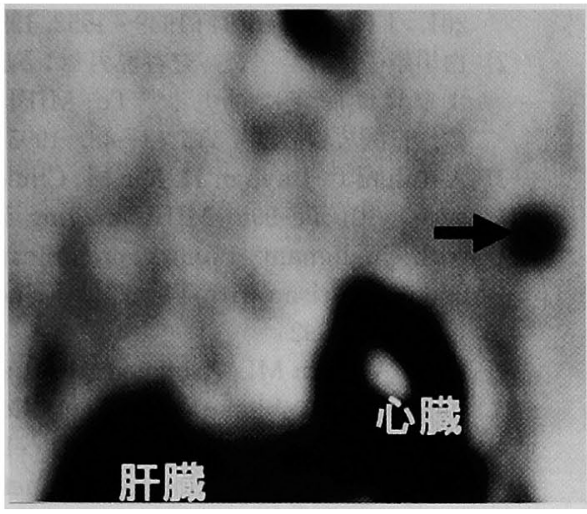

early image

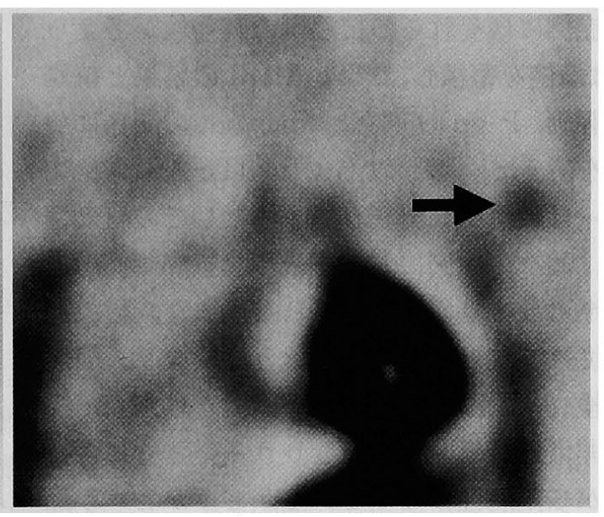

delayed image

図 3 99mTc-MIBI 乳腺シンチグラフィーにおける wash out の診断 38歳女性. 左乳癌患者の冠状断の画像で, early image では左乳腺腫湯に ${ }^{99 m} \mathrm{Tc}-\mathrm{MIBI}$ の取り込 みが認められるが, delayed imageでは取り込みの減少が認められ wash out と診断した。

表 1 a ${ }^{99 m} T c-M I B I$ 乳腺シンチグラフィーによる良悪 性の診断 $\mathrm{P}<0.05$

\begin{tabular}{lcccc} 
& true-positive & true-negative & false-positive & false-negative \\
\hline 悪性腫瘍 & 27 & 0 & 0 & 1 \\
\hline 良性缠瘍 & 0 & 5 & 0 & 0 \\
\hline & & & & $\mathrm{P}<0.05$
\end{tabular}

表 1 b ${ }^{99 m} \mathrm{~T}$ c-MIBI 乳腺シンチグラフィーによる腋窝 リンパ節転移の診断 $\quad P<0.05$

\begin{tabular}{ccccc} 
& true-positive & ure-negative & false-positive & falsc-negative \\
\hline 悪性腫㩧 & 7 & 14 & 0 & 5 \\
\hline & & & & $P<0.05$
\end{tabular}

腫湟径が0.8cm であったことを考えると, ${ }^{99 \mathrm{~m}} \mathrm{Tc}-$ MIBIの検出能の限界を超えていたためと考えられ た.また, 乳癌の腋窩リンパ節転移診断に関しては有 病正診率 $(58 \%)$, 無病正診率 $(100 \%)$, 正診率 $(81 \%)$ であり，これらも他の報告5)6) と同様であった.リンパ 節転移における有病正猃率の減少は, 微小なりンパ節 転移に関してはこの検查法の精度を超えていること と, 原発巣を中心にした場合に腋窝はカメラよりやや 離れてしまうため精度が落ちるものと考えられた。

次に, 臨床的に化学療法が開始初期には有効であっ た薬斧が, ある時期より無効になる現象をしばしば経 験する.またこのとき同時に複数の構造上全く異なる 薬㶡に対しても耐性を示すことが知られていて，この ような多剤耐性に P 糖タンパク (以下 $\mathrm{P}-\mathrm{gp}$ ) が関与し ていることが推測された。薬剤耐性遺伝子として知ら
表 $2{ }^{99 m} \mathrm{~T}$ C-MIBI 乳腺シンチグラフィーによる wash out $の$ 診断

\begin{tabular}{lcc} 
& wash out $(-)$ & wash out $(+)$ \\
\hline 嗮腺腫瘍 & 18 & 8 \\
リンパ節 & 4 & 6 \\
その他 & 3 & 0 \\
\hline wash outを認めた割合 & $36 \%$ (14病変 / 39病変中 )
\end{tabular}

れている MDR1によりコードされ，腫湯細胞膜上に 発現した P-gp は物質選択性にそしく，基質非特異性 を持ち、いろいろな薬剤を細胞内より細胞外へと輸送 するポンプ作用を持つものと考えられている。このた め実際に, 構造上明らかに異なる様々な抗癌剤が $\mathrm{P}-$ gp により排出され, 腫湟が多剂耐性を獲得するものと 考えられている7)8). 多昘耐性腫瘍の画像診断として, P-gpの対するモ/クローナル抗体やコルヒチンの ${ }^{3} \mathrm{H}$ 標識体による PET での報告があるが9), ${ }^{99 m}$ Tc-MIBI が注目されている. ${ }^{99 \mathrm{~m}} \mathrm{Tc}$-MIBI は疎水性で陽性の電 荷を有するため, アドリアマイシン, タキソテール等 の抗癌剤と同様に P-gpのポンプ作用によって細胞内 から細胞外へ排出される。つまり, ${ }^{99 m} \mathrm{Tc}-\mathrm{MIBI} の$ wash out という現象は P-gp 発現と関連していると 考えられている.今回の検討では, 悪性腫漡39病変中 14病変 $(36 \%)$ に wash out が認められた。これらは, アドリアマイシン, タキソテール等の多種の抗癌阂に 耐性を示すことが推测され，また逆に wash outを認 
めなかった症例にはそれらの抗癌剤の有効性が考えら れた. 今後は症例を蓄積し, ${ }^{99 \mathrm{~m}} \mathrm{Tc}-\mathrm{MIBI}$ の結果と抗癌 郕の効果の評価, P-gp の発現と wash out の関係につ いての検討を考えている. 以上より ${ }^{99 \mathrm{~m}} \mathrm{Tc}-\mathrm{MIBI}$ シン チグラフィーは腫瘍シンチグラフィーとしての有効性 だけでなく，個々の症例における最適な抗癌郕使用選 択の判断基準になるものと考えられる。また，組織採 取が必要な従来の抗癌剤感受性試験とは異なり，簡便 で低侵襲の検查で, 即日に結果が評価でき外来での経 過観察にも非常に有効な検查になりうる.さらに今後 は, 癌細胞が多剤而性になっているかどうかという癌 の性状診断への展開が期待できるものと考えられた。

\section{結語}

${ }^{99 m} \mathrm{Tc}-\mathrm{MIBI}$ の良悪性の診断におりる有病正診率 96 $\%$, 無病正診率 $100 \%$, 正診率 $97 \%$ であり,リンパ節転 移診断に関しては有病正診率は $58 \%$, 無病正診率は 100 \%, 正診率 $81 \%$ であった。また悪性腫瘍の $36 \%$ におい て wash out を認めた. 今後は症例を蓄積し,さらに検 討する必要があると考えられた。

$$
\text { 謝辞 }
$$

稿を終えるにあたり御指導を賜りました金沢医科大学第 2 病理学教室の上田善道先生, 桜井礼子先生, 金沢大学核医 学教室の横山邦彦先生に感謝致します。

$$
\text { 文献 }
$$

1) Maublant JC, Zang $Z$, Rapp $M$, et al : In vitro up take of technetium-99m-teboroxime in carcinoma cell lines and normal cells; comparison with technetium-99m-sestamibi and thallium-
201. J Nucl Med 34 : 1949-1952, 1993

2）白川崇子, 森豊, 守谷悦男他：胸腔内悪性お よび良性病変に対する ${ }^{99 m}$ Tc-MIBI の SPECT 像. 日医放線会誌 $55 ： 43-48,1995$

3) Aktolum C, Bayhan H, Kir M: Clinical experience with $T c-99 m-M I B I$ imaging in patients with malignant tumors; preliminary results and comparison with T1-201. J Nucl Med 17 : 171-176, 1992

4) Rao VV, Chiu ML, Kronauge JF, et al : Expression of recombinant human multidrug resistance P-glycoprotein in insect cells confers decreased accumulation of technetium- $99 \mathrm{~m}-$ sestamibi. J Nucl Med 35:510-515, 1994

5）山本俊二, 鍛 利幸, 浮草 実他： ${ }^{99 m} \mathrm{Tc}-\mathrm{MIBI}$ 乳 腺シンチグラフィーによる乳癌および腋窝リンパ 節転移の診断. 臨外 $52: 933-936,1997$

6）福光延吉, 戸崎光宏, 内山真幸他： ${ }^{99 \mathrm{~m}} \mathrm{Tc}-\mathrm{MIBI}$ SPECTによる乳癌ならびにリン八゚節転移の検出 に関する ${ }^{201} \mathrm{Tl}$-SPECT との比較検討. 日医放線会 誌 56:974-979, 1996

7) Chen $\mathrm{CJ}$, Chin JE, Ueda $K$, et al:Internal duplication and homology with bacterial transport proteins in the mdrl (P-glycoprotein) gene from multidrug-resistant human cells. Cell 47 : $381-389,1986$

8) Tsuruo $T$ : Mechanisms of mutidrug resistance and implications for therpy. Jpn J Cancer Res $79: 285-296,1988$

9) Bipin M Mehta, Eddie Rosa, John D Fissekis, et al : In-vivo identification of tumor multidrug resistance with tritium-3-colchicine. J Nucl Med 33 : 1373-1377, 1992

\title{
A PRELIMINARY STUDY OF THE EFFECTIVENESS OF TECHNETIUM-99m-MIBI SCINTIGRAPHY IN BREAST TUMORS
}

\author{
Tomohiko HAYASHI, Nariatsu SATO, Ai NAKAMOTO, Haruo YAGI, \\ Toshiya TAKEDA, Naohiro KOYASAKI, Toru KAMATA and Masahiro KANNO \\ Department of Surgery, Keiju Medical Center
}

We prospectively studied a total of 33 patients ( 5 benign, 28 malignant) with breast mass to evaluate the degree of accumulation of ${ }^{99 m} \mathrm{Tc}-\mathrm{MIBI}$ on scintigraphy. The axillary and breast lesions were evaluated in all patients. All patients had excisional biopsy or surgery after ${ }^{99 m} \mathrm{Tc}-\mathrm{MIBI}$ scintigraphy. The sensitivity of ${ }^{99 m} \mathrm{Tc}$-MIBI scintigraphy for malignant tumor was $96 \%(27 / 28)$, but specificity was $100 \%(5 / 5)$. The sensitivity for axillary lymph node metastasis was $58 \%(7 / 12)$, but specificity was $100 \%$ (14/14). Loss of ${ }^{99 m} \mathrm{Tc}-$ MIBI uptake in lesions in delayed image which was considered to be due to wash out, was seen 14 of 39 lesions (36\%) and was probably related to multidrug resistance. ${ }^{99 m} \mathrm{Tc}-\mathrm{MIBI}$ scintigraphy was able to diagnose this malignancy. This study showed that ${ }^{99 \mathrm{~m}} \mathrm{Tc}-\mathrm{MIBI}$ scintigraphy had a high diagnostic accuracy for the detection of primary breast cancer axillary lymph node metastasis. 